\title{
DISCRIMINATION AND HATE SPEECH AGAINST NORTH KOREAN SCHOOLS IN JAPAN ${ }^{12}$
}

\section{Bruno Alexandre Carvalho ${ }^{3}$ Lilian Yamamoto ${ }^{4}$}

Resumo: Esse artigo ilustra a discriminação sofrida por escolas étnicas no Japão, especialmente aquelas destinadas a crianças coreanas, que enfrentam grandes obstáculos para gozar de seus direitos à educação, incluindo falta de subsídios para suas escolas e isenção de impostos para doadores. Ele também discute a ascensão do discurso de ódio por parte de grupos nacionalistas de direita contra essas escolas e seus alunos, assim como a ineficácia das atuais medidas governamentais para conter esse comportamento. Palavras-chave: Chôsen Gakkô, Discurso de Ódio, Kakushu Gakkô, Zaitokukai, Zainichi.

Abstract: This paper illustrates the discrimination suffered by ethnic schools in Japan today, especially those aimed at Korean children, who face great obstacles to appreciate their rights to education, including a lack of subsidies to their schools and tax exemption opportunities for donators. It also discusses the rise of hate speech from right-wing nationalist groups towards these schools and their students, and the ineffectiveness of current governmental measures to suppress such behavior.

Keywords: Chôsen Gakkô, Hate Speech, Miscellaneous Schools, Zaitokukai, Zainichi Korean.

1 Artigo submetido em 9/10/2018 e aprovado em 13/12/2018.

2 A pesquisa para a elaboração deste artigo foi realizada com apoio da Coordenação de Aperfeiçoamento de Pessoal de Nível Superior (Capes).

3 Mestrando do Programa de Pós-Graduação em Língua, Literatura e Cultura Japonesa (PPGLLCJ) da Faculdade de Filosofia, Letras e Ciências Humanas (FFLCH) da Universidade de São Paulo e Bacharel em História, Universidade de São Paulo (USP), São Paulo, Brasil; bruno.alexandre.carvalho@usp.br (ORCID iD: https://orcid.org/0000-0002-9592-2918).

4 Professora colaboradora do Programa de Pós-Graduação em Língua, Literatura e Cultura Japonesa (PPGLLCJ), da Faculdade de Filosofia, Letras e Ciências Humanas (FFLCH) da Universidade de São Paulo (USP), São Paulo, Brasil; Doutora em Direito Internacional, Universidade Kanagawa; lilianmitsuko@yahoo.it (ORCID iD: https://orcid.org/0000-0002-8304-9509). 


\section{Introduction}

The myth of the homogeneous country and ethnicity that persists in Japan to this day enables conformity and assimilation to dictate what is expected out of students throughout their school life, leaving little room for personal identity and expression. The atmosphere of Japanese High Schools, where corporal punishment is not out of the question and a burdensome workload is mandatory, has led to a steady increase in group bullying against specific individuals (ijime) and school phobia or refusal (tokokyohi) cases. (YONEYAMA, 1999)

Thus, the intellectual development and mental health of students in Japan can be seriously harmed when they are easily singled out and become targets of ijime. This can be especially true for children of ethnic minority groups native to Japan such as the Ainu, Ryûkyû and Burakumin, as well as for foreign nationals living in Japan, such as Brazilians and Peruvian of Japanese descent, the Chinese and Zainichi Korean.

These groups have often had their rights for cultural expression suppressed, as the Japanese school curriculum does not allow for a multicultural approach to teaching and learning (JAPAN NGO NETWORK FOR THE ELIMINATION OF RACIAL DISCRIMINATION, 2014). Cultural diversity and expression have not been as valued or cherished in Japan as they have recently been in other developed countries, leaving minority students with few options other than to abide by these rules or to abandon regular Japanese public schools altogether, in favor of ethnic schools where they can express their cultural identity freely and feel safe while doing so (MOTANI, 2002).

According to the Human Rights Association for Korean Residents in Japan (HURAK), there are many shortcomings regarding education at public schools in the country, such as the lack of education in languages other than Japanese and the lack of activities to raise awareness of discrimination and prejudice against minority groups, which can be strong to the point of leading many students to change their own names for a Japanese sounding one, in order to avoid harassment and discrimination.

Due to the aforementioned issues, ethnic schools are of major importance in Japan, being a safe haven for ethnic minorities to learn their own language and history without fear of being discriminated or singled out by other students or even teachers. (JAPAN NGO NETWORK FOR THE ELIMINATION OF RACIAL DISCRIMINATION, 2014). This paper aims to shed some light on the Zainichi community in Japan, but mostly on the challenges North Korean schools and their students have to face daily.

\section{Zainichi koreans}

Koreans are a long-time minority group in Japan, despite their apparent invisibility and continual struggle to reconcile their identity and fight for recognition as full citizens of Japan. These are immigrants and their descendants who tried to escape the increasing difficulties of life in the Korean peninsula during Japanese colonial domination, or who were simply conscripted into Japanese military service and labor battalions before and 
during World War II. The number of Koreans in Japan reached a peak number of almost 2,4 million people in 1945, but most of the wartime workers decided to return home after the war, leaving around 650,000 Koreans in Japan by the following year (RYANG, 2000).

In 1946, former colonial subjects from Korea and Taiwan lost the right to vote and hold office in Japan, and in 1952, Japan took away citizenship from all Koreans and Taiwanese, including the ones who remained in Japan. The Alien Registration Law of the same year required these subjects to be fingerprinted and carry a certificate of registration. (STRAUSZ, 2007). This fingerprinting requirement was terminated in 1993, and a Special Permanent Resident (Tokubetsu Eijusha) permit came to be in 1991, allowing all Zainichi Koreans and their descendants to live in Japan permanently, despite not having Japanese nationality and no voting rights.

The Korean population is concentrated in urban industrialized areas, such as the Tokyo metropolis and the cities of Osaka, Kyoto, Kobe, Nagoya, Kawasaki and Kitakyushu (RYANG, 1997). As past colonial subjects living in the former Imperial metropolis, they have been treated by some as an unwelcome legacy of Japan's wartime Imperial ambitions, their very existence challenging ubiquitous ideas of Japanese homogeneity and an indivisible link between Japanese nationality and ethnicity (CHAPMAN, 2008).

It is conventional to refer to those affiliated with North Korea as Zainichi Chôsenjin and to those affiliated to South Korea as Zainichi Kankokujin, but the term KoreanJapanese (Kankokukei Nihonjin) has been recently used to demonstrate a third possible identity, independent from affiliation to either North or South regimes. (CHAPMAN, 2008). Regarding Zainichi Korean schools, there are two different branches of ethnic schools available, which are overseen by Mindan and Chongryun, the two main organizations for Koreans living in Japan, the former aligned with the Republic of Korea (hereafter referred to as South Korea) and the later with the Democratic People's Republic of Korea (hereafter North Korea).

Mindan operates the Kankoku gakkô while the Chôsen gakkô are operated under Chongryun supervision. The net of schools sponsored by Chongryun is more far-reaching than that sponsored by Mindan, including one university, twelve high schools, fifity-six middle schools, eighty-one primary schools, and three independent nursery schools (RYANG, 1997). Due to this, these North Korean schools are the focus of this paper.

\section{Legal status and discrimination}

With Chongryun struggling over the seizure of its properties starting in 2012 and money from North Korea becoming scarcer, many of these North Korean schools have had to get by with aid from the Japanese government and donations by students' parents and other supporters in the private sector. These donations are taxed, though. 
Interestingly, donations made by supporters of international schools focused on teaching children of European and North American descent are exempt from these same taxes. Government aid is also limited, due to the legal status that these schools retain.

According to the School Education Act, both Kankoku and Chôsen gakkô are classified as miscellaneous schools, or Kakushu gakkô. This means that the national government is not obliged to grant subsidies to these schools as it is to regular Japanese public schools. This means these institutions share a similar level of government support as driving schools, for example. Local governments are not required to grant subsidies as well, but may do so at their own discretion (JAPAN NGO NETWORK FOR THE ELIMINATION OF RACIAL DISCRIMINATION, 2018).

Unlike the regular Japanese public schools, which are classified under category 1 in the act, foreign schools are also excluded from school lunch provisions by the government and also from health programs. Moreover, graduate certificates from Korean senior high schools are not recognized as qualifications for taking university entrance examinations by many institutions, greatly limiting the access of Korean high school seniors to higher education.

Furthermore, Chôsen gakkô were excluded from the high school tuition waiver program introduced by the Japanese government in 2010, a system which enabled subsidies equivalent to the tuition fees of public senior high schools to be paid to students, effectively making senior high school education free. However, other schools for foreign children were included in the program (JAPAN NGO NETWORK FOR THE ELIMINATION OF RACIAL DISCRIMINATION, 2014). No real explanation for the exclusion was given, but in 2013 Hakubun Shimomura, the then Minister of Education, Culture, Sports, Science and Technology, reasoned the exclusion of Korean schools from the tuition waiver program claiming that the lack of progress in the abduction cases of Japanese citizens by North Korea in the 1970s and 1980s was one of the reasons behind $i^{5}$.

The United Nations Committee on Economic, Social and Cultural Rights (CESCR) expressed its disapproval towards the exclusion of Chôsen gakkô from the tuition fee waiver program in 2013, during its Concluding Observations for that year's round of the Universal Periodic Review (UPR). The reasoning of the exclusive exclusion of these schools was recognized as discriminatory. In spite of that, the ban on Chôsen gakkô has not been lifted by the State, and access to these waivers remains unobtainable to children attending these schools (JAPAN NGO NETWORK FOR THE ELIMINATION OF RACIAL DISCRIMINATION, 2018).

In fact, following the exclusion of Chôsen gakkô from the tuition waver program, other subsidies that used to be granted to these schools were partially cut or halted entirely by local governments, including Tokyo and Osaka. Furthermore, the

5 REYNOLDS, Isabel. North Korean schools in Japan soldiering on despite tough times. The Japan Times. Tokyo, $13^{\text {th }}$ November, 2014. 
Kanagawa Prefectural Government decision to freeze grants to Korean schools in 2013 using nuclear tests by North Korea as reasoning has served as a model of action for other Prefectures. Yokohama City for instance revised its guidelines on subsidies for municipal and private schools for foreign children, including a clause that allowed the City to stop payments according to the climate in the diplomatic sphere.

Due to the aforementioned lower level of financial aid from national and local governments compared to other foreign schools, the persistence of taxes over donations from independent supporters and the fact that Chôsen gakkô senior students are among the very few still paying for their high school tuition means that many of these institutions are currently in a state of decay, as attested by Kim Chol, the head of a Chôsen gakkô located in Osaka.

In a 2014 interview for the Japan Times ${ }^{6}$, Chol stated that the elementary school headed by him had been unable to raise funds for necessary repairs to its aging building, which as it is might not be able to withstand an earthquake. Chol added that his teachers worked almost without pay, as the donations made by supporters and monthly tuition of nearly $¥ 20,000$ per student barely covered the school's expenses. Regarding common criticism that the Chôsen gakkô's educational policies were heavily influenced by Chongryon and its Pyongyang agenda, Chol stated that his school, as well as most pro-Pyongyang elementary and secondary schools for Zainichi Koreans, had removed the portraits of North Korean leaders Kim Il Sung and Kim Jong Il from its walls, due to parents now having diverse political ideas: more than half of the students at his school were actually South Korean nationals.

\section{Hate speech and hate crimes against Chosen Gakko}

Public animosity towards Chongryun due to the organization's ties with North Korea has not helped the case of Chôsen gakkô in general, as the school curriculum not only teaches Korean language and culture, but is also believed to present history by way of biased textbooks that portray the North Korean regime in a positive light. All the textbooks used in Chongryun schools are published by its own publisher, the Hagu Sobang Publishing Company, and children learn that they are overseas nationals of North Korea. Despite this, Japanese is also taught, and the general curriculum is largely based on that of Japanese high schools, so that students are trained to be bilingual and function better within Japanese society, if wanted be (RYANG, 1997).

This positive view of North Korea has been frowned upon by many, including high ranking government members of the Liberal Democratic Party (LDP). This past decade, anti North Korean sentiment in Japan grew considerably over the country's

6 WATANABE, Natsume. Grade School for Zainichi Koreans in Osaka struggling to survive. The Japan

Times, Tokyo, $11^{\text {th }}$ August, 2014. 
nuclear weapons program and missile testing, with the already mentioned abduction of thirteen Japanese nationals by the North Korean regime between 1977 and 1983 also being a known point of contention.

A 2014 poll conducted by BBC and Globe Scan has revealed that an overwhelming $92 \%$ of the Japanese population holds negative views of North Korea, with only $1 \%$ of Japanese respondents expressing positive views. Views of South Korea on the other hand are far more lenient, with half of the respondents expressing indifference over the country's influence, while $37 \%$ view South Korean influence as primarily negative and $13 \%$ as primarily positive. It is noteworthy that the negative perception of both countries by the Japanese population has increased compared to past polls, with views of South Korea even shifting from leaning positive in 2012 to leaning negative in 2013.

The animosity regarding the Korean Peninsula has led to a sharp rise in cases of hate crime and hate speech among the Japanese population toward Zainichi Koreans, especially against those who openly demonstrate allegiance to North Korea or are believed to do so. Students of Korean schools seem to be particularly vulnerable, as shown in multiple reports by the Japanese Non Governmental Organization Network for the Elimination of Racial Discrimination.

According to the Network's 2014 report, after the North Korean government recognized and apologized for the abduction of Japanese nationals at the 2002 JapanNorth Korea summit meeting, more than 1000 cases of hate crime and hate speech against Korean students were reported in the following year alone. But such cases can be traced back even to the 1960s and 1970s, with the most notorious example being the murder of a Korean high school student by Japanese high school students.

The same report also states that since the 1980s, whenever the tension between North Korea and Japan rose, the number of incidents of harassment and violence against Korean schools and their students would rise as well. Roughly three quarters of the cases are instances of verbal abuse, being classified as hate speech, and a quarter is identified as hate crimes, including examples of physical violence such as kicking, punching and spitting. In Osaka alone, half of the Korean junior high school female students have been the subject of such acts (JAPAN NGO NETWORK FOR THE ELIMINATION OF RACIAL DISCRIMINATION, 2014).

A series of demonstrations carried out in front of a Korean elementary school in Kyoto by members of Zaitokukai ${ }^{7}$, a nationalist right-wing group, became notorious between 2009 and 2010. Alleging that the school had illegally occupied a public park near its premises, the group carried out at least three rallies outside the school, using loudspeakers to chant insulting remarks towards the school, which included: "Kick out the worthless Korean Schools from Japan"; "Promises are made between human beings.

7 Zainichi-Tokken o Yurusanai Kai, more commonly referred to as Zaitokukai, is an organization founded with the alleged purpose of informing the Japanese public of the "problems" regarding the "privileges" afforded to the people of Korean heritage in Japan and pressuring the government to abolish such "privileges." (KOTANI, 2018) 
Promises between human beings and Korean will not stand"; "Korean Schools: training institution for Korean spies", among many others. The rallies were filmed and posted online by the protesters, who also damaged school property (KOTANI, 2018).

Since then, Zaitokukai has organized numerous other rallies with hundreds of participants in cities throughout Japan, including Tokyo, Osaka, Kobe, Kyoto and Sapporo, with statements such as "kick out the scum Koreans" and "kill 50,000 Korean prostitutes" being uttered by protesters (JAPAN NGO NETWORK FOR THE ELIMINATION OF RACIAL DISCRIMINATION, 2014a). These remarks are clear stances of hate speech, but since racial discrimination and hate speech have not been outlawed in Japan to this date, protesters could not be legally held accountable for their actions.

Regarding the Kyoto Korean School cases, some of the protesters involved ended up being prosecuted by the government for obstructing the operation of the school and destruction of property. The school also brought civil suits against Zaitokukai and its protesters for the damages caused by the protests, which they won, being granted damages in the amount of 12 million Japanese yen and a provisional disposition injunction against the possibility of future protests. ${ }^{8}$

It is noteworthy that in both criminal and civil cases the involved courts decided that the protesters' racist insults did not amount to hate speech, but to criminal insults in the criminal cases, and civil torts in the civil cases. The success of the lawsuits was in part due to a specific school being continuously targeted by the protesters, but under current legislation, regulating hate speech which targets minorities in general instead of a specific person or association is not an easy task, despite international treaties signed by the Japanese government in the past (KOTANI, 2018).

\section{Current measures against hate speech}

The Japanese government ratified the International Convention on the Elimination of All Forms of Racial Discrimination (ICERD) in December, 1995, thirty years after it was opened for signature and ratification in 1965. But it did not do so without reservations, specifically regarding the fourth article of the Convention, which stated that State Parties should criminalize hate speech and declare illegal organizations which promote and incite racial discrimination. The reservation was made based on the idea that abiding by Article 4 could harm the rights of freedom of speech and assembly guaranteed by the Constitution of Japan:

8 The government prosecuted protesters for damage to property (Penal Code, art. 261), forcible obstruction of business (Penal Code, art. 234), and insults (Penal Code, art. 231). The defendants alleged that their offensive remarks were of political nature and not instances of racial discrimination, but the Kyoto District Court decided that the remarks constituted criminal insult, as they were extremely excessive and senseless. The decision was confirmed by the Osaka High Court in 2011 and the Supreme Court in 2012 (KOTANI, 2018). 
The concept provided by Article 4 may include extremely wide-ranging acts both in various scenes and of various modes. Therefore, to regulate all of them by penal statute exceeding the existing legislation is liable to conflict with guarantees provided by the Constitution of Japan such as freedom of expression, which severely requires both necessity and rationality of the constraint, and the principle of the legality of crimes and punishment, which requests both concreteness and definiteness of the scope of punishment. For this reason, Japan decided to put reservation on Article 4 (a) and (b).

Also, the government does not think that Japan is currently in a situation where dissemination of racial discriminatory ideas or incitement of racial discrimination are conducted to the extent that the government must consider taking legislative measures for punishment against dissemination of racial discriminatory idea, etc. at the risk of unjustly atrophying lawful speech by withdrawing the above reservation. ${ }^{9}$

The reservation seems to ignore that racial discrimination cannot be restrained by the existing legal system in a quick, effective manner, also downplaying the extent of hate speech and hate crimes in Japanese soil. The reasoning behind it being that other domestic anti-defamation laws unrelated to racial discrimination could take effect in such cases, so as not to infringe one's right to speak freely. In trying to balance constitutional values and sociological harms that hate speech legislation seeks to address, it seems that the line gets drawn in favor of the constitutional right to freedom of expression, with courts not recognizing the harms caused by hate speech as being very grave (MARTIN, 2018).

Since ratifying the Convention in 1995, the Japanese government has not lifted its reservation despite continuous advisements by CERD, but has admitted that hate crimes are on the rise in Japan and that affirmative action must be taken, as seen on the preamble to the Act on the Promotion of Efforts to Eliminate Unfair Discriminatory Speech and Behavior against Persons Originating from Outside Japan (hereafter Anti Discriminatory Speech Act), from 2016:

In recent years in Japan, unfair discriminatory speech and behavior are being practiced to incite the exclusion of persons and their descendants, who are residing lawfully in Japan, from local communities in our country by reason of such persons originating from a country or region other than Japan, therefore imposing tremendous pain and suffering on such persons and their descendants, and causing serious rifts in the local community.

Obviously, such unfair discriminatory speech and behavior should not exist, and tolerating such a situation is not permissible in light of Japan's position in the international community.

It is therefore declared that such unfair discriminatory speech and behavior will not be tolerated, and, accordingly, this Act is to be enacted to spread awareness among the general public and to promote their understanding and cooperation through further

9 ARUDOU, Debito. Embedded Racism: Japan's Visible Minorities and Racial Discrimination. Minneapolis: Lexington Books, 2015, pp. 257-258. 
human rights education and awareness-raising activities, and to strengthen efforts to eliminate unfair discriminatory speech and behavior. ${ }^{10}$

The Act asserts that the government is to implement measures to eliminate hate speech, but does not provide detailed information on how this will be done, what these measures will be and when they are going to be implemented. It does not stipulate any sort of action plan or allocate budget for the purpose of eliminating hate speech. The Act also does not impose any sort of penalty or punishment on its violators, failing to declare hate speech illegal. Its definition of what constitutes hate speech is also limited, focusing only on unfair speech and behavior against foreign legal residents, ignoring asylum seekers and indigenous local minorities, such as the Ainu and Ryûkyû:

\begin{abstract}
In this Act, "unfair discriminatory speech and behavior against persons originating from outside Japan" shall mean unfair discriminatory speech and behavior to incite the exclusion of persons originating exclusively from a country or region other than Japan or their descendants and who are lawfully residing in Japan (hereinafter referred to in this Article as "persons originating from outside Japan") from the local community by reason of such persons originating from a country or region other than Japan, such as openly announcing to the effect of harming the life, body, freedom, reputation or property of, or to significantly insult, persons originating from outside Japan with the objective of encouraging or inducing discriminatory feelings against such persons originating from outside Japan. ${ }^{11}$
\end{abstract}

Presenting a narrow definition of who the victims of racial discrimination are and providing no punishment to perpetrators of hate speech whatsoever, the 2016 Anti-Discriminatory Speech Act does not bring much advancement to the protection of minorities as one might have expected, as only a few minorities, Zainichi Koreans included, are contemplated by it. It is still a step forward for the Japanese government, though. The state party has admitted that hate speech is on the rise and something must be done about it, but the current bill does not make a significant difference in the lives of minorities in Japan, legal residents or not.

Regarding Zainichi Koreans, the 2016 Anti-Discriminatory Speech Act acknowledges the harassment Korean children endure to express their ethnic heritage should not be tolerated, but that is as far as the law in its current form goes. Korean schools also remain unprotected from attacks by right-wing groups, so the status quo remains unchallenged. Although the number of participants has

10 MINISTRY OF JUSTICE. Act No. 68 of 2016. The Act on the Promotion of Efforts to Eliminate Unfair Discriminatory Speech and Behavior against Persons Originating from Outside Japan (Anti-Discriminatory Speech Act), 2016, pp.1

11 MINISTRY OF JUSTICE. Act No. 68 of 2016. The Act on the Promotion of Efforts to Eliminate Unfair Discriminatory Speech and Behavior against Persons Originating from Outside Japan (Anti-Discriminatory Speech Act), 2016, pp.2 
decreased following the bill, which counts as a positive development, there were no changes in the number of hate propaganda speeches by organizations such as Zaitokukai on the streets following the bill, which is over 200 times a year (JAPAN NGO NETWORK FOR THE ELIMINATION OF RACIAL DISCRIMINATION, 2018). In addition to Koreans, Zaitokukai also targets Chinese, Burakumin, migrant workers, as well as other minority groups.

\section{Conclusion}

The Japanese government should consider changing its stance regarding ethnic Korean schools, as its current one is discriminatory. In order to change this, the state party should consider including these institutions in the tuition waiver program, regardless of their perceived bias for Pyongyang, also pressing local governments to lift subsidy granting based on international politics and making donations to these schools eligible for tax exemptions. The later should also be extended to the other miscellaneous schools that are still treated differently, such as Chinese or Brazilian institutions, effectively supporting every ethnic school in Japan equally, thus allowing minority children to fully enjoy their rights to education. The State should also consider treating graduation from foreign schools on the same footing as Japanese senior high school graduation, allowing these children the same chance of entering higher education as any other student.

Putting into action a comprehensive bill that outlaws hate speech is another pressing matter that should be analyzed by the Japanese government. The 2016 AntiDiscriminatory Speech Act, although commendable, is not efficient enough in its current form; its definition of what discrimination is should be rewritten and expanded to include indigenous minorities and non-Japanese without residency papers. A new, comprehensive built-in mechanism that punishes discriminatory behavior should also be considered for inclusion. Lifting the reservation to the fourth article of the ICERD is advisable as well, as it would show the government is strengthening its human rights mechanisms and taking the treaties it has signed in the past seriously, respecting minorities and their rights, citizens or not. Such gestures of goodwill would demonstrate the state party's willingness to embrace diversity in a deep, meaningful way.

\section{Bibliographic Reference}

AKUZAWA, Mariko. Changing Patterns of Discrimination in Japan: Rise of Hate Speech and Exclusivism on the Internet, and the Challenges to Human Rights Education. Taiwan Human Rights Journal, Taipei: Soochow University, Vol. 13, No. 4, December, 2016.

ARUDOU, Debito. Embedded Racism: Japan's Visible Minorities and Racial Discrimination. Minneapolis: Lexington Books, 2015.

ASIA-PACIFIC HUMAN RIGHTS INFORMATION CENTER. Rise of Hate Speech in Japan. FOCUS Asia Pacific, Osaka: HURIGHTS OSAKA, Vol. 74, December, 2013. 
CHAPMAN, David. Zainichi Korean Identity and Ethnicity. First Press, New York: Routledge, 2008.

GLOBESCAN. BBC 2014 Country Rating Poll. 2014. Available at: < https://downloads.bbc. co.uk/mediacentre/country-rating-poll.pdf $>$

HUMAN RIGHTS COUNCIL. Compilation on Japan: Report of the Office of the United Nations High Commissioner for Human Rights. 2017. Available at: < https://documentsdds-ny.un.org/doc/UNDOC/GEN/G17/257/44/PDF/G1725744.pdf>

HUMAN RIGHTS COUNCIL. Summary of Stakeholders' submissions on Japan. 2017. Available at: < https://documents-dds-ny.un.org/doc/UNDOC/GEN/G17/245/42/PDF/ G1724542.pdf>

HUMAN RIGHTS NOW. Fact-finding Report: The Realities of Hate Speech Against Korean Residents in Japan. November, 2014. Available at: < http://hrn.or.jp/eng/wp-content/ uploads/2015/12/Hate-Speech-report-English-translation.pdf $>$

JAPAN NGO NETWORK FOR THE ELIMINATION OF RACIAL DISCRIMINATION. Civil Society Report on the Implementation of the ICERD. August, 2014. Available at: < https://tbinternet.ohchr.org/Treaties/CERD/Shared\%20Documents/JPN/INT_CERD_ NGO_JPN_17538_E.pdf>

JAPAN NGO NETWORK FOR THE ELIMINATION OF RACIAL DISCRIMINATION. Joint Civil Society Report on Racial Discrimination in Japan. August, 2018. Available at: $<$ https://tbinternet.ohchr.org/Treaties/CERD/Shared\%20Documents/JPN/INT_CERD_ NGO_JPN_31918_E.pdf>

JAPAN NGO NETWORK FOR THE ELIMINATION OF RACIAL DISCRIMINATION. NGO Report on The Issue of Hate Speech in relation to the Issue No. 10 of the List of Issues adopted by the Human Rights Committee. 2014. Available at: < https://tbinternet. ohchr.org/Treaties/CCPR/Shared\%20Documents/JPN/INT_CCPR_CSS_JPN_17357_E.pdf>

KOTANI, Junko. Proceed with Caution: Hate Speech Regulation in Japan. Hastings Constitutional Law Quarterly. San Francisco: University of California, Hastings College of Law, Vol. 45, No. 3, 2018.

MARTIN, Craig. Striking the Right Balance: Hate Speech Laws in Japan, the United States, and Canada. Hastings Constitutional Law Quarterly. San Francisco: University of California, Hastings College of Law, Vol. 45, No. 3, 2018.

MINISTRY OF JUSTICE. Act No. 68 of 2016. The Act on the Promotion of Efforts to Eliminate Unfair Discriminatory Speech and Behavior against Persons Originating from Outside Japan (Anti-Discriminatory Speech Act), 2016. Available at: <http://www.moj.go.jp/ content/001199550.pdf>

MOTANI, Yoko. Towards a More Just Educational Policy for Minorities in Japan: The case of Korean Ethnic Schools. Comparative Education. London: Taylor \& Francis, Volume 38, Issue 2, pp. 225-237, 2002.

OSAKI, Tomohiro. Nationalism rearing ugly head with greater frequency. The Japan Times, 
Tokyo, 23rd May, 2014.

OSAKI, Tomohiro. Diet debates hate-speech bill that activists call narrow and toothless. The Japan Times, Tokyo, 19 ${ }^{\text {th }}$ April, 2016.

PENNEY, Matthew; WAKEFIELD, Bryce. Right Angles: Examining Accounts of Japanese Neo-Nationalism. Pacific Affairs. Vancouver: University of British Columbia, Vol. 81, No. 4, pp.537-555, 2009.

REYNOLDS, Isabel. North Korean schools in Japan soldiering on despite tough times. The Japan Times, Tokyo, 13 ${ }^{\text {th }}$ November, 2014.

RYANG, Sonia. North Koreans in Japan: Language, ideology and identity. London: West View Press, 1997.

RYANG, Sonia. The North Korean homeland of Koreans in Japan. In RYANG, Sonia. Koreans in Japan: Critical Voices from the Margin. Taylor \& Francis, 2000.

STRAUSZ, Michael. Minorities and Protest in Japan: The Politics of the Fingerprinting Refusal Movement. Pacific Affairs. Vancouver: University of British Columbia, Vol. 79, No. 4, pp. 641-656, 2007.

WATANABE, Natsume. Grade School for Zainichi Koreans in Osaka struggling to survive. The Japan Times, Tokyo, 11 $1^{\text {th }}$ August, 2014.

YONEYAMA, Shoko. The Japanese high school: silence and resistance. Digital Edition, London: The Nissan Institution / Routledge Japanese studies series, Taylor Francis Group, 2001. 